Rev. Biol. Trop., 15(2): 207.219. 1968

\title{
Two new trematodes from the intestine of a yellow bat, Nycticeius kuhlii from Lucknow, India
}

\author{
by \\ Vinod Agrawal* \\ (Received for publication April 14, 1966)
}

A large number of trematodes were collected from the small intestine of a yellow bat, Nycticeius kublii from Lucknow, India. As they differ from known species they are being described as new species under the respective genera.

Family: LECITHODENDRIIDAE Odhner, 1910

Prosthodendrium (Paralecithodendrium) thapari sp. nov.

(Figs. 1-3)

DESCRIPTION: Body more or less oval, narrower anteriorly, broader and notched at posterior end, smocth, $0.56-1.32 \mathrm{~mm}$ long by $1.05-1.20 \mathrm{~mm}$ wide. Oral sucker subterminal, oval or spherical, $0.10-0.17 \mathrm{~mm}$ long by $0.10-0.18 \mathrm{~mm}$ wide. Ventral sucker preequatorial, spherical, smaller than oral sucker, 0.07-0.11 $\mathrm{mm}$ long by $0.08-0.11 \mathrm{~mm}$ wide at $0.27-0.47 \mathrm{~mm}$ from anterior extremity. Prepharynx absent; pharynx 0.25-0.055 mm long by 0.025-0.070 mm wide; esophagus short, $0.01-0.03 \mathrm{~mm}$ long; intestinal ceca nearly transverse extending up to anterior margin of testes. V-shaped.

Excretory pore a little anterior to posterior end of body. Excretory bladder

Genital pore in front of ventral sucker, $0.27-0.49 \mathrm{~mm}$ from anterior extremity.

Testes equal or subequal, spherical or triangular, symmetrical, lying in

* Lecturer in Zoology, Liniversity of Lucknow, I.ucknow, U. P. India. 
acetabulat region. Right testis $0.14-0.27 \mathrm{~mm}$ long by $0.12-0.34 \mathrm{~mm}$ wide, at $0.26-0.45 \mathrm{~mm}$ from anterior extremity. Left testis, $0.15-0.25 \mathrm{~mm}$ long by 0.14 . $0.33 \mathrm{~mm}$ wide at $0.25-0.50 \mathrm{~mm}$ from anterior extremity. Cirrus pouch elongated or flask shaped, lying transversely anterior to acetabulum, $0.19-0.27 \mathrm{~mm}$ long by $0.07-0.09 \mathrm{~mm}$ wide. Bipartite seminal vesicle, broader at posterior end and narrower at anterior end, $0.100-0.112 \mathrm{~mm}$ long by $0.032-0.050 \mathrm{~mm}$ wide; pars prostica well developed, $0.21-0.25 \mathrm{~mm}$ long by $0.01-0.11 \mathrm{~mm}$ wide; ejaculatory duct, $0.082-0.120 \mathrm{~mm}$ long, opening into genital atrium.

Ovary deeply lobed, pretesticular, inter-testicular or may overlap margins of testes, $0.10-0.24 \mathrm{~mm}$ long by $0.22 \cdot 0.53 \mathrm{~mm}$ wide at $0.13-0.40 \mathrm{~mm}$ from anterior extremity. Oviduct arises from posterioz side of ovary and enters oötype which lies close to ventral sucker. A large number of sinall Mehlis's gland cells surround oötype. Vitellaria follicular, extending from anterior region of oral sucker either anterior to testes or overlapping them. The right and left vitelline ducts meet to form a common duct opening at cötype. Uterus arises from posterior end of oötype, with transversely coiled limbs cccupying entire space of hindbody. Eggs, $0.010-011 \mathrm{~mm}$ long by $0.005-0.005 \mathrm{~mm}$ wide.

Discussion: The present form belongs to the genus Prosthodendrium (Paralecithodendrium) Dollfus, 1931. Dubors (1) revised the subgenus Parale. cithodendrium Odhner, 1911 and considered the following six species as valid with their synonymy: Prosthodendrium (Paralecithodendrium) glindulosum (Looss 1896), syn. Distomum glandulosum Looss, 1896, D. obtusum Looss, 1896 et prohablement $D$. chefrenianum Looss, 1896; P. (P.) nokomis Macy, 1937, syn. Prosthodendrium (Paralecithodendrium) lucifugi Miacy, 1937; P. (P.) ovimagnosum (Bhalerao, 1926), syn. Lecithodendrium osimagnossm Bhalerao, 1926, L. asadai Fuki et Ogata, 1938, Paralecithodendriım magnioris Gupta et Bhardwaj, 1958; P. (P.) aranbai Lent, de Freitas et Proença, 1945 syn. Paralecitboderdrium bracbycolon de Freitas et Dobbin, 1960; P. (P.) molensampi Lie Kian Joe, 1951 and $P$. (P.) bepaticum Chen, 1954, syn. Lecitbodendrium ovimagrosum Tubangui, 1928 nec. Bhalerao, 1926, Prosthodendrium ovimagnosum compactum Chen, 1954. He removed the following from the subgenus: P. liliputianum Travassos, 1928 which is accepted as a species of Edcabrllerotrema Freitas, 1960; P. skrjabini Sha!dibin, 1948 which may be a member of Limasulum Travassos, 1921; Prostbo. dendrium (Paralecithodendrium) tetralobulatum Caballero, 1943, and P. (P.) paeminosum Caballero, 1943 are considered synonyms of $P$. (P.) naviculum Macy, 1936. Lecithodendrium anticum Stafford, 1905 attributed to Paralecithodendrium by Ohdner, 1905 is considered a species inquirenda.

The new form differs from $P$. (P.) aranbai in not having the ventral sucker larger than oral sucker. It resimbles $P$. (P.) glandulosum $P$. (P.) nokomis, $P$. (P.) ovimagnosum, $P$. (P.) Molenkampi and $P$. (P.) bepaticum is having ventral sucker smaller than oral sucker. The new form however differs from all these forms in the structure and position of the cirrus pouch, in the position of the genital pore and in the extension of vitellaria up to anterior region of oral sucker. 
The present form is, therefore, new and designated as $P$. thapari sp. nov., in honor of Dr. G. S. Thapar, retired Professor of Zoology, University of Luck. now, Lucknow, U. P. India.

Host: Nycticeius kublii Rafinesque, 1819.

LOCATION: Small intestine.

LOCALITY: Lucknow.

Family: DICROCOELIIDAE Odhner, 1911

\section{Anchitrema lucknowensis sp. nov.}

\section{(Fig. 4)}

Diescruptron: Body elongate; portion of body anterior to testes spinose, with rounded extremities, $1.3-2.6 \mathrm{~mm}$ long by $0.54-0.71 \mathrm{~mm}$ wide. Oral sucker subterminal, round, $0.12-0.30 \mathrm{~mm}$ long by $0.225-0.275 \mathrm{~mm}$ wide. Ventral sucker spherical, smaller than oral sucker, close to anterior border of testes, 0.14-0.20 $\mathrm{mm}$ long by $0.14-0.21 \mathrm{~mm}$ wide at $0.31-0.67 \mathrm{~mm}$ from anterior extremity. Prepharynx absent; pharynx well developed, $0.08-0.10 \mathrm{~mm}$ long by $0.75-0.100 \mathrm{~mm}$ wide; esophagus short, $0.025-0.040 \mathrm{~mm}$ long; intestinal ceca simple, extending parallel to body wall to posterior end of body.

Excretory pore at posterior end of body. It leads into a short wide tube which divides into two lateral limbs one on either side.

Genital pore submedian, lying on anterior border of aperture of ventral sucker at $0.35-0.70 \mathrm{~mm}$ from anterior extremity.

Testes oval, subequal, symmetrical, preequatorial; right testis $0.25-0.45$ $\mathrm{mm}$ long by $0.17-0.25 \mathrm{~mm}$ wide at $0.43-0.79 \mathrm{~mm}$ from anterior extremity. Left testis $0.25-0.51 \mathrm{~mm}$ long by $0.14-0.22 \mathrm{~mm}$ wide at $0.38-0.82 \mathrm{~mm}$ from anterior extremity. Cirrus sac flask-shaped, $0.30-0.52 \mathrm{~mm}$ long by $0.10-0.11 \mathrm{~mm}$ wide lying medially in front of ventral sucker either close to or overlapping its anterior border, at $0.37-0.49 \mathrm{~mm}$ from anterior extremity. Vesicula seminalis tubular, spirally coiled or S-shaped, 0.26-0.45 mm long by 0.02-0.03 mm wide. Cirrus short, muscular, $0.65-0.125 \mathrm{~mm}$ long, opening at genital pore. A large number of prostate gland cells fill entire space in cirrus sac around vesicula seminalis.

Ovary nearly mediao, lying either between testes or immediately posttesticular, measuring $0.15-0.22 \mathrm{~mm}$ long by $0.14-0.21 \mathrm{~mm}$ wide at $0.55-1.12 \mathrm{~mm}$ from anterior extremity. From its posterior end arises oviduct which opens into ötype. A pear shaped receptaculum seminis $0.038-0.10 \mathrm{~mm}$ long by $0.045-0.050$ $\mathrm{mm}$ wide lies at posterior end of ovary and opens into oötype. Vitellaria follicular, arranged on sides of body extending from middle region of testes to $0.38-0.48$ $\mathrm{mm}$ from posterior end of body. Two transverse vitelline ducts of each side join together to form a common yolk duct which opens at oötype. A large number of unicellular Mehils's gland cells surround oötype and open into it. Uterus arises fram posterior end of oötype, filling the posterior half of body, consisting of 
several transverse coils with ascending and descending limbs. Ascending limb passes forward on left or right side of ventral sucker and opens at genital pore. Eggs $0.020-0.025 \mathrm{~mm}$ long by $0.10-0.15 \mathrm{~mm}$ wide.

Discussion: Sonsino (1894)* described Distomum sanguineum from the gut of Chameleo viulgaris. Looss (2) erected a new ganus Ancbitrema to accomodate this species as type. Subsequently two other species were assigned to this genus, viz. A latum Gedoelst, 1919 and $A$. sokolowi (Skrjabin, 1914) Dollfus, 1929, syn. Mesocoelium sokolowi. Thapar (4) reported the occurrence of a new trematode, Exorchoeliusm indicum, from the intestine of a yellow bat Nyct cejus kubliz from Lucknow. PANDE (3) consid?red it synonymous with Anchitrema sanguineum Looss, 1899.

Thapar (5) obtained a few more specimens from the same host and made a critical study, besides other characters, mainly of the morphology of the excretory system. He distinguished this genus from the genus Anchitrema in the complete absence of body spines, in the presence of a distinct cirrus sac and the presence of the receptaculum seminis and in the possession of a typical $\mathrm{Y}$. shaped excratory system, characteristics of the family Dicrocoeliidae. The author does not agree with THAPAR and considers that the characters mentioned by h'm are also present in the genus Anchitrema. In the genus Anchitrema the cirrus pouch is occupied by a convoluted seminal vesicle immediately preacetabular, the receptaculum seminis is formed by dilation of basal portion of Laurer's canal, and the excretory system is $\mathrm{Y}$-shaped. The presence or absence of spines is a variable character even within the species. Hence there is no character quoted by THAPAR that can be used to separate Exorchocoelium from Anchitrema and the two there. fore are identical.

YamaguTl (6) lists 5 species in the genus Anchitrema, of which two have bien transferred from other genera considered by YAMAGUir to be synonymous with Anchitrema, viz. Platynosomum philippinorum Tubangui, 1928 and Platynosomum philippinorum congolense Sandground, 1937.

Under the genus Anchitrema, the new form resembles closely $A$. indiczsni (syn. Exorchocoeliusn indicum) but differs from it in having spines on the anterior border of body, in the extension of vitellaria from middle region of testes to some distance short of posterior extremity, in having geniml pore in the anterior horder of acetabulum, in having subequal testes, in having a flask. shaped cirrus sac and in tha smaller size of eggs. (Thapar gave the size of recep. taculum seminis as $0.42 \mathrm{~mm}$ by $0.16 \mathrm{~mm}$ which should, probably, read $0.042 \mathrm{~mm}$ $\mathrm{mm}$ by $0.016 \mathrm{~mm}$; the eggs are said to measure $0.19 \mathrm{~mm}$ in length and $0.02 \mathrm{~mm}$ in breadth; this should, probably, read $0.019 \mathrm{~mm}$ in length and $0.02 \mathrm{~mm}$ in breadth).

The present form is, therefore, new and designated $A$. luscknowensis sp. nov.

* Original literature not consulted. 
Host: Nycticeizs kublii Rafinesque, 1819.

LOCATION: Small intestine.

LOCALJTY: Lucknow.

\section{ACIKNOWLEDGMIENT}

The work has been carried out under the direction of Dr. S. P. Gupta, Reader in Zoology, University of Lucknow, Lucknow. The author is greatly indebted to him for his valuable help end encouragement.

\section{RESUIMEN}

Se describøn dos especies nuevas de tremátodos, parásitos intestinales del murciélago amarillo Nycticeius kublii: Prostbodendrium (Pralecitbodendrium) thapari, y Anchitrema lucknowensis.

\section{SUMMARY}

Prosthodendrium (Paralecithodendrium) thapari sp. nov. and Ancbitrema lucknowensis sp. nov., from the small intestine of a yeliow bat, Nycticeius kubliz are described.

\section{LITERATURE CITED}

1. Dubois, $G$.

1962. Contribution à l'étude des Trematodes de Chiroptères. Revision du sous-genre Paralecithodendrium Odhner 1911. Rev. Sisisse Zool., 69: 385407.

2. Looss, A.

1899. Beitr ge zur Kenntnis der Trematodenfauna Aegyptens, zugleich Versuch einer natürlichen Gliederung des Genus Distomum Retzius, Zool. Jabrb. Syst., 12: S21-784.

3. PANDE, B. P.

1935. Contributions to the digenetic trematodes of the Microchiroptera of Northern India. Part I. New species of the genus Pycnoporus with a note on Anchitrema. Proc. Acad. Sci., 4: 371-380.

4. THAPAR, G.S.

1931. On a new trematode from the intestine of yellow bat, Nycticejus kublii. Proc. Ind. Sci. Cong., 18: 220.

5. THAPAR, G.S.

1956. On the morphology and systematic position of a new genus of trematodes from the intestine of the yellow bat, Nycticejus kublii. Ind. J. Helmintbol., 8: 85-91.

6. YAMAGUTI, $\mathrm{S}$.

1958. Systema Helmintbum. Interscience Publishers New Yorḱ. London. Vol. 1 \& 2: 1.979 . 
Figs. 1 to 3. Prosthodendrissn (Posalecitbodendristm) tiopati so. aow.

Fig. 1. Dorsal viewo.

Fig. 2. Cirrus pouch eniarged.

Fig. 3. Oätype enlarged.

Fig. 4. Archisrema laschenerasis sp. nov. Veatral vies. 

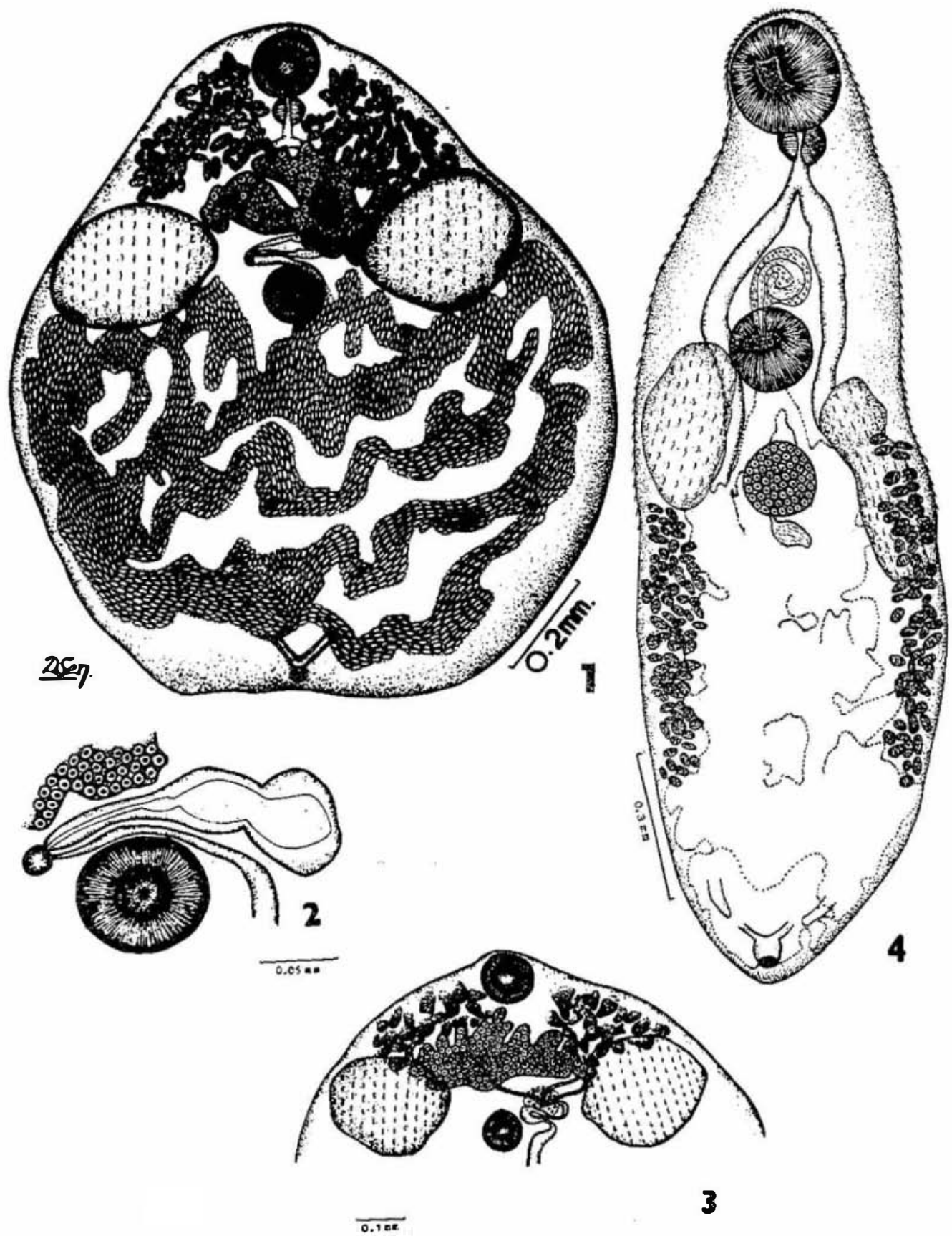